\title{
MENINGKATKAN KEMAMPUAN BERBICARA SISWA MELALUI MODEL PEMBELAJARAN ROLE PLAYING DI KELAS V SD NEGERI 2 BATARAGURU KOTA BAUBAU
}

\author{
Muniati \\ Dinas Pendidikan, Pemuda, dan Olahraga Kota Baubau, SD Negeri 2 Bataraguru \\ E-mail:muniati@gmail.com
}

\begin{abstract}
Abstrak
Tujuan penelitian ini untuk mengetahui efektivitas model pembelajaran Role Playing di kelas V SD Negeri 2 Bataraguru. Penelitian ini dilaksanakan di Kelas V SD Negeri 2 Bataraguru pada semester ganjil tahun pelajaran 2014/2015. Hasil penelitian menunjukan bahwa hasil belajar siswa dapat ditingkatkan melalui model Pembelajaran Role Playing di Kelas V SD Negeri 2 Bataraguru. Hal ini ditunjukkan oleh hasil peningkatan sebagai berikut: (1) Hasil belajar yang dicapai oleh siswa kelas V SD Negeri2 Bataraguru, yaitu pada siklus I persentase hasil belajar siswa secara klasikal sebesar $45 \%$ dengan nilai rerata 65 dan pada siklus II persentase ketuntasan meningkat menjadi 85\% dengan nilai rerata 74; (2) Aktivitas mengajar guru siklus I pertemuan pertama diketahui memperoleh nilai sebesar $43 \%$, dan pertemuan kedua mengalami peningkatan sebesar $64 \%$. Sedangkan siklus II pertemuan pertama sebesar $71 \%$, dan pertemuan kedua mengalami peningkatan sebesar 93\%; (3) Aktivitas belajar siswa siklus I pertemuan pertama sebesar $45 \%$, dan pertemuan kedua mengalami peningkatan sebesar $63 \%$. Sedangkan siklus II pertemuan pertama sebesar $73 \%$, dan siklus II pertemuan kedua mengalami peningkatan sebesar $82 \%$, maka aktivitas belajar siswa melalui model pembelajaran menulis karangan melalui media gambar di kelas sudah terlaksana.
\end{abstract}

Kata kunci: berbicara, model pembelajaran, Role Playing.

\begin{abstract}
The purpose of this study to determine the effectiveness of learning model Role Playing in class V SD Negeri 2 Bataraguru. This research was conducted in Class V SD Negeri 2 Bataraguru in odd semester of academic year 2014/2015. The results showed that student learning outcomes can be improved through the model of Role Playing Learning in Class V SD Negeri 2 Bataraguru. This is indicated by the results of the improvement as follows: (1) The learning outcomes achieved by the students of grade V SD Negeri2 Bataraguru, that is in the cycle I the percentage of student learning outcomes by classical $45 \%$ with a mean value of 65 and in cycle II the percentage of mastery increased to $85 \%$ with a mean value of 74; (2) Teacher first cycle teaching activity first meeting is known to get a score of $43 \%$, and the second meeting has increased by $64 \%$. While the first cycle of the first meeting was $71 \%$, and the second meeting increased by 93\%; (3) Student learning activity first cycle of the first meeting of $45 \%$, and the second meeting increased by $63 \%$. While the first cycle of the first meeting amounted to $73 \%$, and the second cycle of the second meeting experienced an increase of $82 \%$, then the learning activities of students through the learning model writing essay through the media in the classroom image has been done.
\end{abstract}

Keywords: talking, learning model, Role Playing. 


\section{SANG PENCERAH}

Volume 3, Nomor 2, Februari 2017, Hlm. 41-49

Muniati: Meningkatkan Kemampuan Berbicara Siswa ...

\section{Pendahuluan}

Pembelajaran bahasa Indonesia diarahkan untuk meningkatkan kemampuan peserta didik untuk berkomunikasi dalam menggunakan bahasa Indonesia dengan baik dan benar, baik secara lisan maupun tulis, serta menumbuhkan apresiasi terhadap hasil karya kesastraan Indonesia. Pembelajaran bahasa Indonesia secara formal mencakup pengetahuan kebahasaan dan keterampilan berbahasa. Pengetahuan kebahasaan meliputi pembelajaran mengenai asal-usul bahasa, tata bahasa, kebakuan dan sebagainya. Dalam pembelajaran bahasa terdapat empat aspek keterampilan yang meliputi mendengarkan, berbicara, menulis serta membaca.

Menurut Tarigan (1981) keterampilan membaca dan menyimak merupakan keterampilan yang bersifat produktif, yang dituntut untuk menghasilkan sesuatu berdasarkan kemampuan yang dimiliki oleh seseorang yang berupa ide, gagasan atau menghasilkan sebuah produk. Karena sifatnya yang menghasilkan produk, maka keterampilan berbicara dianggap oleh sebagian orang merupakan hal yang sangat sulit.selain itu, pembelajaran berbicara di kelas lebih sedikit porsinya. Pembelajaran berbicara yang diajarkan di Kelas V SD merupakan salah satu materi keterampilan berbahasa yang dapat dikatakan suatu pembelajaran yang sangat sulit bagi siswa. Kadang kala siswa merasa malu tampil di depan kelas untuk berbicara, seperti memperkenalkan nama, menceritakan tentang pengalaman dan lain sebagainya.

Pembelajaran berbicara sangat tepat diberikan kepada siswa untuk belajar berkomunikasi. Siswa dapat melakukan latihan berbicara secara individual atau kelompok, tergantung situasi dan kondisi sekolah serta karakteristik siswa. Kemampuanberbicara merupakan salah satu komponen kompetensi dasar yang harus dimiliki oleh siswa. Artinya kemampuan berbicara adalah keterampilan yang harus diajarkan oleh siswa ketika belajar Bahasa Indonesia di sekolah.

Pembelajaran berbicara di SD Negeri 2 Bataraguru Kota Baubaumasih belum efektif. Hal ini tampak pada saat observasi guru hanya menugaskan siswa untuk membuat teks dialog saja atau menyuruh siswa untuk memperhatikan/melihat di media tanpa memperhatikan seluruh aspek yang menentukan dan mendukung keterampilan berbicara siswa, misalnya mempraktikkan langsung teks dialog. Selain itu, hasil ulangan hariansemester I tahun 2013/2014 menunjukkan bahwa dari 20orang siswa Kelas V SDN 2 Bataraguru, yang memperoleh nilai $\geq 70$ hanya 7 orang atau $35 \%$, sedangkan siswa yang memperoleh nilai $\leq 70$ sebanyak 13 orang atau $65 \%$. Hal ini, belum memenuhi standar Kriteria Ketuntasan Minimal (KKM) yang ditetapkan sekolah, yakni sebesar 70. Rendahnya nilai perolehan siswa ini disebabkan guru yang menerapkan strategi pembelajaran tidak variatif. Oleh karena itu, perlu dicari suatu alternatif pembelajaran di Kelas V SD Negeri 2 Bataraguruagar dapat meningkatkan hasil belajar siswa.

Model pembelajaran role playing (bermain peran) adalah salah satu model pembelajaran yang telah diuji oleh beberapa ahli dan berhasil. Namun, dewasa ini model pembelajaran ini jarang digunakan dalam proses pembelajaran. Padahal dalam masalah pembelajaran yang berdimensi individual seperti keterampilan berbicara sangat baik digunakan karena model ini menawarkan pembelajaran untuk menyelesaikan masalah dari dimensi kecakapan individu masing-masing siswa maupun sosial. Zuhairini (1983) menyatakan role playing adalah cara atau jalan untuk mendramatisasikan cara bertingkah laku orang-orang tertentu didalam posisi yang membedakan peranan masing-masing. Apabila ditinjau secara istilah, metode role playing adalah bentuk metode mengajar dengan mendramakan/ memerankan cara 


\section{SANG PENCERAH}

Volume 3, Nomor 2, Februari 2017, Hlm. 41-49

Muniati: Meningkatkan Kemampuan Berbicara Siswa ...

bertingkah laku dalam hubungan sosial, yang lebih menekankan pada kenyataankenyataan dimana para murid diikutsertakan dalam memainkan peranan di dalam mendramakan masalah-masalah hubungan sosial. Metode ini kadang-kadang disebut dengan dramatisasi. Berdasarkan deskripsi di atas, fokus penelitian ini adalah bagaimana meningkatkan kemampuan berbicara siswa melalui model pembelajaran Role Playing di kelas V SD Negeri 2 Bataraguru?

Tujuan penelitian ini untuk mengetahui efektivitas model pembelajaran Role Playing di kelas V SD Negeri 2 Bataraguru.

\section{Metode Penelitian}

\section{Jenis Penelitian}

Penelitian ini adalah jenis Penelitian Tindakan Kelas (PTK) atau Classroom Action Research. Penelitian yang merupakan suatu pencermatan dalam kegiatan belajar berupa sebuah tindakan, yang sengaja dimunculkan dan terjadi dalam sebuah kelas secara bersama (Arikunto, dkk., 2008). Karakteristik khas dari penelitian ini adalah adanya tindakan (aksi) yang dilakukan oleh guru untuk memperbaiki proses belajar mengajar di kelas (Muhtar, 2000). Penelitian ini dilaksanakan sebanyak dua siklus dengan mengacu pada model Kemmis dan Mc Taggart (Susilo, dkk., 2009). Tindakan yang dilakukan dalam penelitian ini adalah penerapan metode Role Playing. Pendekatan yang digunakan dalam penelitian ini adalah pendekatan kuantitatif dan kualitatif.

\section{Waktu dan Tempat Penelitian}

Penelitian ini dilaksanakan di Kelas V SD Negeri 2 Bataraguru pada semester ganjil tahun pelajaran 2014/2015. Penelitian ini dilaksanakan dengan mempertimbangkan continuum dari materi yang diajarkan pada kurikulum.

\section{Subjek Penelitian}

Subjek penelitian ini adalah siswa Kelas V SD Negeri 2 Bataraguru dengan jumlah siswa 20 orang, yang terdiri dari 8 orang siswa laki-laki, dan 12 orang siswa perempuan. Penelitian ini dilaksanakan pada saat mata pelajaran Bahasa Indonesia berlangsung dengan kompetensi dasar "Berwawancara sederhana dengan nara sumber (petani, nelayan, karyawan, dll) dengan memperhatikan pilihan kata dan santun berbicara".

\section{Prosedur Penelitian}

Prosedur penelitian yang akan dijadikan acuan dalam penelitian ini adalah Metode penelitian tindakan kelas Kurt (Arikunto, 2006:16), yakni perencanaan (planning), pelaksanaan (acting), observasi (observing), dan pengamatan (observing). Refleksi (reflecting). Hubungan keempat komponen tersebut dipandang sebagai siklus.

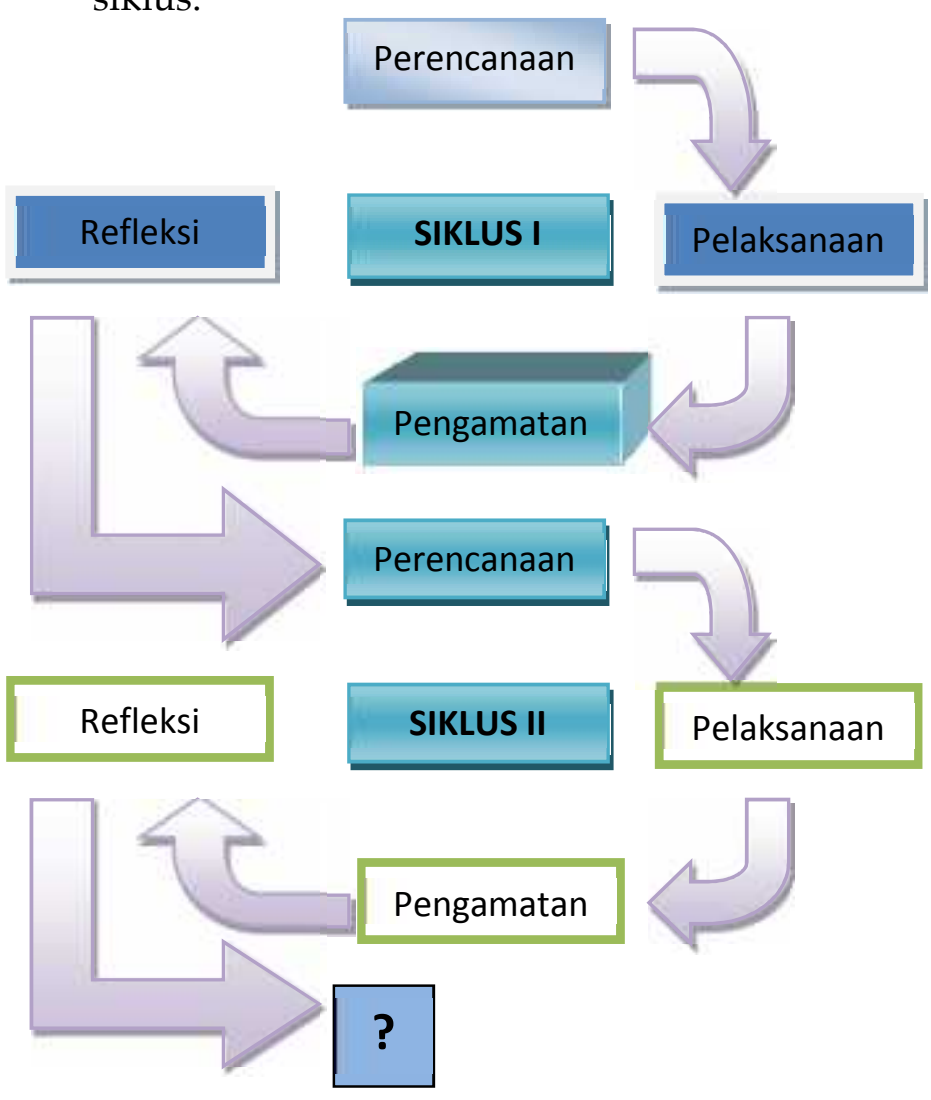

Gambar 1 Model PTK diadaptasi dari Kurt Lewin 


\section{SANG PENCERAH}

Volume 3, Nomor 2, Februari 2017, Hlm. 41-49

Muniati: Meningkatkan Kemampuan Berbicara Siswa ...

\section{Data, Instrumen, dan Teknik Pengumpulan Data}

Data yang diambil adalah data kuantitatif dari hasil tes, observasi selama selama kegiatan pembelajaran serta data kualitatif yang menggambarkan keaktifan siswa, antusias siswa, partisipasi dan kerjasama dalam diskusi, kemampuan atau keberanian siswa dalam berwawancara.Rumus yang digunakan untuk mengetahui aktivitas guru ketika mengajar diolah menggunakan tehnik Persentase (\%). Adapun rumus yang digunakan adalah sebagai berikut.

\section{Aktivitas Guru= $\frac{\text { Skoryangdiperoleh }}{\text { Skor Maksimal }} \times 100 \%$}

Memes (2001)

Hasil observasi aktivitas mengajar guru Bahasa Indonesia di kelas V SD Negeri 2 Bataraguru ketika menggunakan model pembelajaran role playing dianalis dengan menggunakan kriteria:

Tabel 1 Konversi Nilai Aktifitas Mengajar Guru

\begin{tabular}{lcl}
\hline \multicolumn{1}{c}{ Kriteria } & Nilai & \multicolumn{1}{c}{ Penafsiran } \\
\hline Baik sekali & $86-100$ & $\begin{array}{l}\text { Aktivitas mengajar } \\
\text { guru baik sekali } \\
\text { Aktivitas mengajar } \\
\text { guru baik }\end{array}$ \\
Baik & $71-85$ & $\begin{array}{l}\text { Aktivitas mengajar } \\
\text { guru cukup } \\
\text { Aktivitas mengajar } \\
\text { guru kurang } \\
\text { Aktivitas mengajar } \\
\text { guru sangat kurang }\end{array}$ \\
Kurang & $56-70$ & $41-45$ \\
Sangat Kurang & $<40$ &
\end{tabular}

Hasil observasi aktivitas siswa Kelas V SD Negeri 2 Bataraguru ketika diajar dengan menggunakan model pembelajaran Role Playing, yaitu:

Aktivitas Siswa $=$
$\frac{\text { JumlahSiswaYangAktif }}{\text { JumlahTotal Siswa }} \times 100$

Memes (2001)

Hasil observasi aktivitas belajar siswa tersebut dikonversi dengan kriteria interprestasi data persentasi hasil observasi adalah:

Tabel 2 Konversi Nilai Aktifitas Belajar Siswa

\begin{tabular}{lcl}
\hline \multicolumn{1}{c}{ Kriteria } & Nilai & \multicolumn{1}{c}{ Penafsiran } \\
\hline Baik sekali & $86-100$ & $\begin{array}{l}\text { Aktivitas belajar } \\
\text { siswa baik sekali } \\
\text { Aktivitas belajar } \\
\text { Biswa baik }\end{array}$ \\
Cukup & $71-85$ & $\begin{array}{l}\text { Aktivitas belajar } \\
\text { siswa cukup } \\
\text { Aktivitas belajar } \\
\text { siswa kurang } \\
\text { Aktivitas belajar } \\
\text { siswa sangat kurang }\end{array}$ \\
\hline
\end{tabular}

Memes (2001)

Untuk mengetahui peningkatan hasil belajar siswa Kelas V SD Negeri 2 Bataraguru ketika diajar dengan menggunakan model pembelajaran role playing, yaitu:

$$
\begin{aligned}
& \text { M } \\
& \begin{array}{l}
\text { eSkorPerolehan } \\
\text { mSkor Maksimal }
\end{array} 100=\ldots \ldots . . . . \\
& \text { e } \\
& \text { S Depdiknas (2001) } \\
& \text { Peningkatan hasil belajar siswa Kelas } \\
& \text { V SD Negeri 2 Bataraguru ketika diajar } \\
& \text { dengan menggunakan model pembelajaran }
\end{aligned}
$$




\section{SANG PENCERAH}

Volume 3, Nomor 2, Februari 2017, Hlm. 41-49

Muniati: Meningkatkan Kemampuan Berbicara Siswa ...

role playing, selanjutnya dikonversi dengan kriteria:

Tabel 3 Konversi Nilai Hasil Observasi

\begin{tabular}{lrl}
\hline \multicolumn{1}{c}{ Kriteria } & Nilai & \multicolumn{1}{c}{ Penafsiran } \\
\hline Baik sekali & $86-100$ & $\begin{array}{l}\text { Hasil belajar siswa baik } \\
\text { sekali }\end{array}$ \\
Baik & $71-85$ & $\begin{array}{l}\text { Hasil belajar siswa baik } \\
\text { Hasil belajar siswa } \\
\text { Cukup }\end{array}$ \\
cukup \\
Kurang & $41-45$ & $\begin{array}{l}\text { Hasil belajar siswa } \\
\text { kurang }\end{array}$ \\
\hline & & Depdiknas (2004)
\end{tabular}

Sebagai indikator keberhasilan dalam penelitian tindakan kelas ini adalah jika minimal 80\% siswa telah memperoleh nilai minimal 70 (ketentuan dari sekolah/SKBM). Seorang siswa dikatakan telah mencapai ketuntasan belajar secara individual apabila siswa tersebut telah mendapat nilai $\geq 75$ (ketentuan dari sekolah/Standar Ketuntasan Belajar Minimal (SKBM)).

Rumus yang digunakan untuk menghitung ketuntasan individual sebagai berikut.

$$
T P=\frac{n}{N} X 100
$$

Keterangan:

$\mathrm{TP}=$ Persentase Penguasaan Materi

$\mathrm{n} \quad=$ Skor yang diperoleh Siswa

$\mathrm{N}=$ Skor Maksimal

Rumus yang digunakan untuk menghitung ketuntasan klasikal sebagai berikut.

$$
P=\frac{\sum n}{N} X 100
$$

Keterangan:

$\mathrm{P} \quad=$ Nilai Ketuntasan Belajar

$\sum n=$ Jumlah Siswa yang Tuntas Secara Individu

$\mathrm{N}=$ Jumlah Total Siswa

Jika data sudah menunjukkan $85 \%$ dari jumlah total siswa telah menguasai materi yang diajarkan, berarti pembelajaran sudah dapat dikatakan efektif tetapi bila belum sesuai dengan kriteria tersebut dapat dikatakan belum efektif. Perbaikan tindakan pembelajaran perlu dilakukan ke siklus berikutnya.

\section{Teknik Analisis Data}

Teknik analisis data yang digunakan mengacu pada teknik yang dikembangkan oleh Miles dan Huberman (Susilo, dkk., 2009) yang terdiri atas tahapan yaitu: (1) mereduksi data; (2) menyajikan data; dan (3) menyajikan kesimpulan.

\section{Pembahasan}

Hasil observasi aktivitas mengajar guru (Gambar 2.) menunjukkan bahwa pada siklus I persentase aktivitas guru mencapai $34 \%$. Hal ini menunjukkan bahwa aktivitas guru dalam proses pembelajaran berada pada kategori belum baik. Masih ada beberapa kelemahan dalam pelaksanaannya, seperti pada kegiatan awal, guru dalam penggalian informasi (apersepsi) tentang materi pelajaran belum terlalu mendalam dan penyampain tujuan pembelajaran. Pada kegiatan inti, kelemahan-kelemahan guru seperti penjelasan tentang langkah-langkah role playing belum begitu jelas, cara guru belum membimbing siswa untuk memahami peran/tokoh dalam teks dialog sesuai lafal, intonasi dan ekspresi dan mengorganisir siswa untuk tampil membawakan dialog belum maksimal, Pada kegiatan penutup, guru langsung menyimpulkan materi yang diajarkan, tanpa ada komentar dari siswa.

Hasil observasi pada siklus I pertemuan kedua menunjukkan bahwa ada peningkatan aktivitas guru yakni mencapai 64\%. Nilai tersebut menunjukkan bahwaterjadi peningkatan aktivitas guru sebanyak 31,31\%. Hal ini menunjukkan bahwa aktivitas guru dalam proses pembelajaran sudah berada pada kategori baik. Meskipun demikian, masih ada beberapa kelemahan dalam pelaksanaannya, 


\section{SANG PENCERAH}

Volume 3, Nomor 2, Februari 2017, Hlm. 41-49

Muniati: Meningkatkan Kemampuan Berbicara Siswa ...

seperti pada kegiatan awal, pemberian motivasi dan apersepsi belum terlalu Nampak. Kelemahan-kelemahan pada tindakan siklus I kemudian dilakukan perbaikan dengan melaksanakan tindakan siklus II. Hasil refleksi tersebut menjadi pedoman dalam pelaksanaan tindakan siklus II. Hasil observasi aktivitas guru pada siklus I pertemuan kedua mencapai $71 \%$. Hal ini menunjukkan bahwa aktivitas guru dalam proses pembelajaran sudah berada pada kategori baik. Meskipun masih ada aspek yang belum semuanya terlaksana.

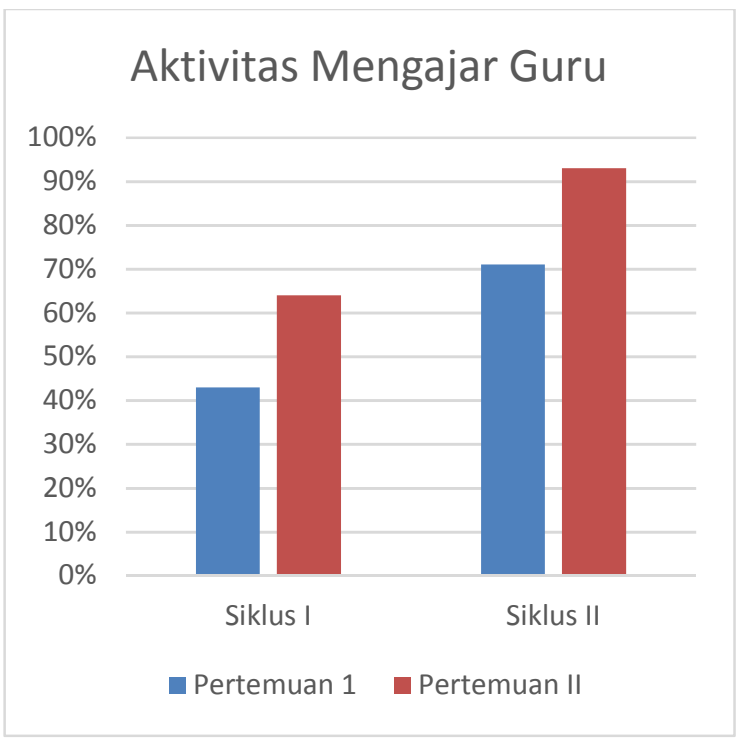

\section{Gambar 2 Persentase Aktivitas Mengajar Guru Setiap Pertemuan}

Pada pertemuan kedua siklus II aktivitas mengajar guru mencapai $93 \%$. Menunjukkan bahwa terjadi peningkatan sebanyak $11,12 \%$. Ini berarti bahwa aktivitas mengajar guru telah mencapai indikator kinerja yang ditetapkan dalam penelitian ini yaitu $\geq 80 \%$. Hal ini, bahwa pembelajaran berbicara melalui model bermain peran/role playing yang dilakukan oleh guru terlaksana dengan baik. Hal ini, sejalan dengan pendapat Patmodewo (2000:107) bahwa bermain peran sangat menyenangkan bagi anak, mambawa mereka ke dunia bermain, sehingga anak termotivasi untuk belajar.

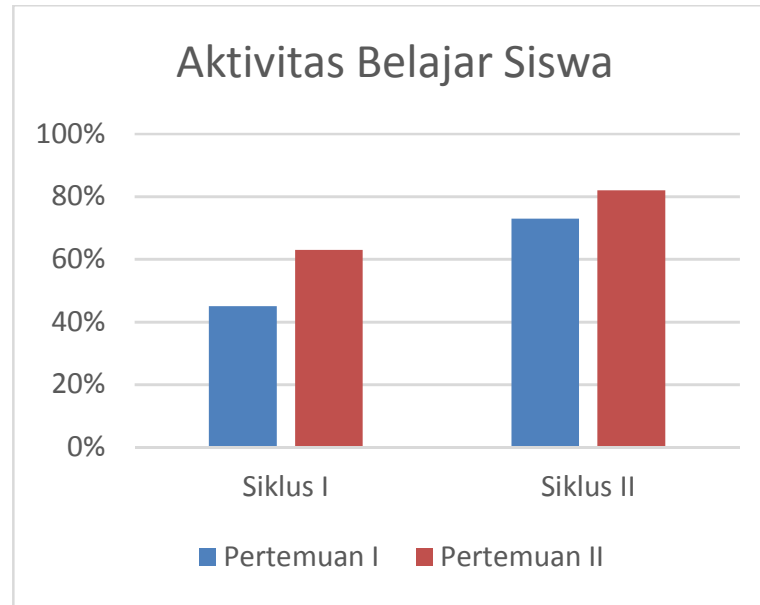

\section{Gambar 3 Persentase Aktivitas Belajar Siswa Setiap Pertemuan}

Hasil observasi aktivitas belajar siswa (Gambar 3) menunjukkan bahwa pada siklus I pertemuan pertama presentase sktivitas belajar siswa mencapai $45 \%$. Hal ini menunjukkan bahwa aktivitas belajar siswa belum berada pada kategori baik. Masih ada beberapa kelemahan dalam pelaksanaannya, seperti perhatian siswa yang tidak fokus pada penjelasan guru, siswa belum termotivasi dalam belajar, masih ada siswa yang belum berani mengemukakan pertanyaan sehubungan dengan kegiatan pementasan, siswa belum semuanya terlibat dalam menyimpulkan materi.

Hasil observasi pada siklus I pertemuan kedua menunjukkan bahwa ada peningkatan aktiivitas belajar siswa yakni mencapai $64 \%$. Nilai tersebut menunjukkan bahwa terjadi peningkatan aktivitas belajar siswa sebanyak $31,31 \%$. Hal ini menunjukkan bahwa aktivitas belajar siswa sudah berada pada kategori baik. Meskipun demikian, masih ada beberapa kelemahan dalam pelaksanaannya, seperti siswa belum semuanya memberikan perhatian saat guru melakukan apersepsi, siswa belum semuanya memperhatikan penjelasan guru, dan siswa belum berani mengemukakan tanggapan/masukannya. 


\section{SANG PENCERAH}

Volume 3, Nomor 2, Februari 2017, Hlm. 41-49

Muniati: Meningkatkan Kemampuan Berbicara Siswa ...

Tabel 4 Data Tes Hasil Belajar Siswa Siklus

\begin{tabular}{cccc}
\hline I & Kategori & Frekuensi & $\begin{array}{c}\text { Persentase } \\
\mathbf{( \% )}\end{array}$ \\
\hline $75-90$ & Sangat Baik & 3 & 15 \\
$65-74$ & Baik & 6 & 30 \\
$45-64$ & Cukup & 11 & 55 \\
\hline \multicolumn{2}{c}{ Jumlah } & 20 & 100 \\
\hline \% Jumlah Siswa $\leq 65$ & 11 & 55 \\
\hline
\end{tabular}

Kelemahan-kelemahan pada tindakan siklus I dilakukan perbaikan dengan melaksanakan tindakan siklus II. Hasil refleksi tersebut menjadi pedoman dalam pelaksanaan tindakan siklus II. Sedangkan Hasil observasi aktivitas belajar siswa pada siklus II pertemuan pertama mencapai $73 \%$. Hal ini menunjukkan bahwa aktivitas belajar siswa sudah berada pada kategori baik. Meskipun masih ada aspek yang belum semuanya terlaksana. Pada pertemuan kedua siklus II aktivitas belajar siswa mencapai $82 \%$. Menunjukkan bahwa terjadi peningkatan sebanyak $10,10 \%$. Ini berarti bahwa aktivitas siswa telah mencapai indikatir kinerja yang ditetapkan dalam penelitian ini yaitu $\geq 80 \%$. Hal ini sejalan dengan pendapat Catron dan Alien dalam Sudijono (2009) yang mengatakan bahwa bermain peran memiliki tujuan utama yakni memelihara pertumbuhan dan perkembangan optimal anak melalui pendekatan bermain yang reaktif, interaktif, dan terintegrasi dengan lingkungan bermain anak, sehingga terjalin komunikasi yang baik antara anak yang satu dengan anak yang lainnya.

Tabel 5 Data Tes Hasil Belajar Siswa Siklus

\begin{tabular}{cccc}
\multicolumn{2}{c}{ II } & & \\
\hline Skor & Kategori & Frekuensi & $\begin{array}{c}\text { Persentase } \\
\mathbf{( \% )}\end{array}$ \\
\hline $75-90$ & Sangat baik & 7 & $35 \%$ \\
$65-74$ & Baik & 10 & $50 \%$ \\
$45-64$ & cukup & 3 & $15 \%$ \\
\hline \multicolumn{2}{c}{ Jumlah } & 20 & $100 \%$ \\
\hline \% Jumlah Siswa $\geq \mathbf{6 5}$ & 17 & $85 \%$ \\
\hline
\end{tabular}

Peningkatan aktivitas mengajar guru dan aktivitas belajar siswa dalam pembelajaran bahasa Indonesia pada tiap siklusnya berpengaruh terhadap meningkatnya kemampuan berbicara siswa kelas V SD Negeri 2 Bataraguru. Dari hasil tes tindakan (Tabel 3 dan 4) menunjukkan peningkatan kemampuan berbicara dari data hasil belajar pada semester genap tahun pelajaran 2014/2015 sampai dengan siklus II, dimana pada tes awal (hasil ulangan harian) diperoleh rerata kemampuan berbicara siswa sebesar $65 \%$ dengan presentase ketuntasan 35\%. Berdasarkan hasil tersebut, maka dilakukan tindakan perbaikan pembelajaran bahasa Indonesia dengan menerapkan model pembelajaran role playing. Pada tindakan siklus I pertemuan pertama, para siswa belum semuanya aktif dalam pembelajaran, karena model pembelajaran yang diterapkan guru merupakan hal yang baru bagi mereka, sehingga dalam pelaksanaannya belum begitu maksimal. Kegiatan pembelajaran pada siklus I pertemuan pertama ini belum maksimal karena siswa belum termotivasi dalam belajar, siswa tidak memperhatikan penjelasan guru pada saat apersepsi dan penyampaian tujuan pembelajaran.

Pada pertemuan kedua siklus I, siswa sudah mulai ada peningkatan aktivitas belajar, meskipun masih ada beberapa aspek yang belum maksimal dilakukan. Setelah diadakan evaluasi hasil belajar siklus I, diperoleh rerata nilai hasil belajar siswa mencapai $65 \%$ dengan presentase ketuntasan $45 \%$. Atau hanya 9 siswa dari 20 siswa yang tuntas belajarnya. Walaupun sudah terjadi peningkatan kemampuan berbicara siswa jika dibandingkan dengan nilai ulangan harian (tes awal), namun belum memenuhi indikator kinerja yang ditetapkan dalam penelitian yaitu $\geq 85 \%$ siswa memperoleh KKM yang ditetapkan sekolah yaitu $\geq 70$.

Berdasarkan pencapaian kemampuan berbicara siswa pada siklus I, maka perlu diadakan perbaikan pembelajaran siklus II 


\section{SANG PENCERAH}

Volume 3, Nomor 2, Februari 2017, Hlm. 41-49

\section{Muniati: Meningkatkan Kemampuan Berbicara Siswa ...}

guna memperbaiki kelemahan-kelemahan yang terjadi pada siklus I. Berdasarkan hasil observasi pada tindakan siklus II, menunjukkan bahwa ada peningkatan yang cukup signifikan terhadap kemampuan berbicara siswa yang mencapai rerata 74 dengan presentase ketuntasan $85 \%$. Atau sebanyak 17 siswa dari 20 siswa yang telah tuntas belajarnya. Dengan demikian telah memenuhi indicator kinerja yang ditetapkan dalam penelitian ini yaitu $\geq 85 \%$ siswa memperoleh nilai KKM yang ditetapkan sekolah yaitu $\geq 70$.

Peningkatan kemampuan berbicara siswa kelas V SDN 2 Bataraguru yang dicapai tersebut selain dipengaruhi oleh penerapan model pembelajaran role playing, juga disebabkan oleh peningkatan aktivitas mengajar guru dan aktivitas belajar siswa. Hal ini sejalan dengan pendapat Dahlan Dien (2005) yang mengatakan bahwa tujuan utama pembelajaran bahasa adalah meningkatkan keterampilan berbicara siswa serta pengetahuan tentang bahasa. Materi pembelajaran berbicara yang baik selalu memenuhi berbagai kriteria. Kriteria itu berkaitan dengan tujuan, bahan, pembinaan keterampilan proses, dan pengalaman belajar.

Berdasarkan pencapaian ketuntasan ketiga faktor yang diteliti tersebut, maka penelitian ini dikatakan telah berhasil dan dihentikan sampai pada siklus II. Ini berarti bahwa hipotesis tindakan telah terjawab yaitu aktivitas mengajar guru, aktivitas belajar siswa, dan kemampuan berbicara siswa dalam pembelajaran bahasa Indonesia pada siswa kelas V SD Negeri 2 Bataraguru dapat ditingkatkan melalui penerapan model pembelajaran role playing.

\section{Simpulan}

Simpulan penelitian ini bahwa hasil belajar siswa dapat ditingkatkan melalui model Pembelajaran Role Playing di Kelas V SD Negeri 2 Bataraguru. Hal ini ditunjukkan oleh hasil peningkatan sebagai berikut: (1) Hasil belajar yang dicapai oleh siswa kelas V SD Negeri2 Bataraguru, yaitu pada siklus I persentase hasil belajar siswa secara klasikal sebesar $45 \%$ dengan nilai rerata 65 dan pada siklus II persentase ketuntasan meningkat menjadi $85 \%$ dengan nilai rerata 74 ; (2) Aktivitas mengajar guru siklus I pertemuan pertama diketahui memperoleh nilai sebesar $43 \%$, dan pertemuan kedua mengalami peningkatan sebesar $64 \%$. Sedangkan siklus II pertemuan pertama sebesar $71 \%$, dan pertemuan kedua mengalami peningkatan sebesar 93\%; (3) Aktivitas belajar siswa siklus I pertemuan pertama sebesar $45 \%$, dan pertemuan kedua mengalami peningkatan sebesar $63 \%$. Sedangkan siklus II pertemuan pertama sebesar 73\%, dan siklus II pertemuan kedua mengalami peningkatan sebesar $82 \%$, maka aktivitas belajar siswa melalui model pembelajaran menulis karangan melalui media gambar di kelas sudah terlaksana.

\section{Daftar Pustaka}

Arikunto, S., Suhardjono, dan Supardi. 2008. Penelitian Tindakan Kelas. Jakarta: Bumi Aksara.

Dahlan Dien, Chuzaima. 2005. Lingua, Jurnal Bahasa dan Sastra. Palembang: JPBSFKIP.

Memes. 2001. Evaluasi Pembelajaran. Yogyakarta: UNY Press.

Muhtar. 2007. Penelitian Tindakan Kelas. Jakarta: Dirjen Dikdasmen.

Sudijono, Anas. 2009. Konsep Dasar Pendidikan Anak Usia Dini. Jakarta: PT Indeks. 


\section{SANG PENCERAH}

Volume 3, Nomor 2, Februari 2017, Hlm. 41-49

Muniati: Meningkatkan Kemampuan Berbicara Siswa ...

Susilo, H., Chotimah, H., dan Sari, Y.D. 2009. Penelitian Tindakan Kelas Sebagai Sarana Pengembangan Keprofesionalan Guru dan Calon Guru. Malang: Bayumedia.

Tarigan, H.G. 1981. Berbicara Sebagai Suatu Keterampilan Berbahasa. Bandung: Angkasa.

Zuhairini. 1983. Ilmu Pendidikan Islam. Jakarta: Rineka Cipta. 